Journal of Biomedical and Pharmaceutical Research

Available Online at www.jbpr.in CODEN: - JBPRAU (Source: - American Chemical Society) Index Copernicus Value: $\mathbf{7 2 . 8 0}$

PubMed (National Library of Medicine): ID: (101671502) Volume 7, Issue 6: November-December: 2018, 01-09

Research Article
ISSN (Online): 2279-0594

ISSN (Print): 2589-8752

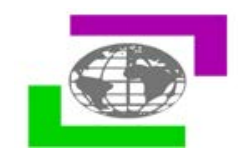

\title{
FORMULATION AND EVALUATION OF FAST DISSOLVING TABLETS OF VALDECOXIB
}

K Kareemuddin Ansari ${ }^{1}$, Neeraj Sharma ${ }^{2}$

${ }^{1}$ College of Pharmacy, Sri Satya Sai University of Technology \& Medical Sciences, Pachama, Sehore466001-MP, India.

${ }^{2}$ School of Pharmacy, Madhyanachal Professional University, Ratibad, Bhopal, M.P., India

Article Info: Received 10 October 2018; Accepted 15 November. 2018

Cite this article as: Ansari, K. K., \& Sharma, N. (2018). FORMULATION AND EVALUATION OF FAST

DISSOLVING TABLETS OF VALDECOXIB. Journal of Biomedical and Pharmaceutical Research, 7(6).

DOI: https://doi.org/10.32553/jbpr.v7i6.558

Address for Correspondence: K Kareemuddin Ansari, College of Pharmacy, Sri Satya Sai University of Technology \& Medical Sciences, Pachama, Sehore-466001-MP, India.

Conflict of interest statement: No conflict of interest

\section{ABSTRACT:}

Valdecoxib is a selective COX- II inhibitor with anti - inflammatory, analgesic and antipyretic properties. The poor aqueous solubility of the drug leads to variable dissolution rates. In the present study an attempt has been made to prepare fast dissolving tablets of Valdecoxib in the oral cavity with enhanced dissolution rate. The fast dissolving tablets of Valdecoxib was prepared with some carriers (polymers) and super disintegrants such as Polyvinyl Pyrrolidone (PVP), Sodium Carboxy Methyl Cellulose (SCMC), Crospovidone NF and $\beta-$ Cyclodextrin. The above mentioned all carriers and superdisintegrants were taken in different proportions of 5,10 , and $15 \%$. All the formulations of the fast dissolving tablets of Valdecoxib were prepared by direct compression technique. The blend was examined for Angle of repose, Bulk density, Compressibility index and Hausner's ratio. The prepared tablets were evaluated for hardness, drug content uniformity, friability, disintegration time and dissolution rate. An effective pleasant testing formulation released $99.88 \%$ drug within 10 minutes. The prepared formulations drug release was found to be comparable with the marketed dispersible tablets.

Keywords: Fast dissolving tablets, Super-disintegrants, Valdecoxib, Crosspovidone, Sodium Carboxy Methyl Cellulose.

\section{INTRODUCTION}

A fast dissolving system can be defined as a solid dosage form for oral administration, which when placed in mouth, rapidly dispersed or dissolved and can be swallowed in the form of liquid. Fast dissolving tablets are solid tablets and designed to dissolve/disintegrate in the patient's mouth within few seconds or minutes, without the need to drink or chew ${ }^{1}$.
The fear of taking solid tablets and the risk of choking for certain patient populations still exist despite their short disintegration/ dissolution times. However some patients, particularly pediatrics and geriatric patients have difficulty swallowing or chewing solid dosage forms (conventional dosage forms) to fear of choking and unwillingness ${ }^{2}$. Fast dissolving and fast dispersing drug delivery system may offer a solution to these problems. 
When the fast disintegrating tablet is orally applied, the drug substance has to be dissolved so that can be absorbed. Dissolution process consists of various processes, e.g. wetting, disintegration and dissolution. Fast disintegrating tablets which are generally contains several excipients are involved in complex series of dissolution process that begin when the solvent contacts the solid and penetrates the tablet matrix $^{3}$. Effect of excipients is assumed to be related to the surface properties of the particles and solid matrix structure ${ }^{4,5}$. Valdecoxib is chemically 4(5- methyl- 3- phenyl - 4 - isoxazolyl) benzene sulfonamide and is a diaryl substituted isoxazole derivative. It is a nonsteroidal anti-inflammatory drug (NSAID) that exhibits anti-inflammatory, analgesic and antipyretic properties. The mechanism of action is believed to be due to inhibition of prostaglandin synthesis primarily through inhibition of cyclooxygenase - 2 (COX - 2). Hence oral administration of Valdecoxib is useful in the treatment of variety of painful inflammatory condition, including those associated with osteoarthritis, rheumatoid arthritis, moderate to severe primary dysmenorrheal, sports injuries can be well treated with Valdecoxib. Valdecoxib is available as tablets and gels. Treatment of the signs and symptoms of osteoarthritis and rheumatoid arthritis $10-40 \mathrm{mg} /$ day dose is required. Due the low aqueous solubility of the Valdecoxib, the bioavailability of the conventional dosage form is low. The poor aqueous solubility of the drug leads to variable dissolution rates. In the present study an attempt has been made to prepare fast dissolving tablets of Valdecoxib in the oral cavity with enhanced dissolution rate.

\section{MATERIALS AND METHODS}

Valdecoxib was obtained as gift sample from Halmak Pharmaceuticals Pvt. Ltd, Secunderabad. Polyvinyl Pyrrolidone (PVP), Sodium Carboxy Methyl Cellulose (SCMC),
Crospovidone NF and $\beta$ - Cyclodextrin were procured from S.S.R Enterprises, Tirupati. All other chemicals and solvents used were of analytical grade.

\section{PREPARATION OF MIXED BLEND OF DRUG AND EXCIPIENTS}

All the materials were passed through sieve no. 60. Required quantity of each ingredient was taken for each specified formulation (Mentioned in Table no. 1) and all the ingredients were subjected to grinding to a required degree of fineness (except magnesium stearate). The powdered blend was evaluated for flow properties as follows.

\section{Angle of repose ${ }^{6}$}

Angle of repose was determined using fixed funnel method. The blend was poured through a funnel that can be raised vertically until a maximum cone height (h) was obtained. Radius of the heap $(r)$ was measured and the angle of repose $(\theta)$ was calculated using the formula.

$\theta=\tan -1(h / r)$

\section{Bulk density ${ }^{6}$}

Bulk density was determined by pouring the blend into a graduated cylinder. The bulk volume (V) and weight of the powder (M) was determined. The bulk density was calculated by using the below mentioned formula,

Bulk density $=$

Mass of granules

Volume of granules

\section{Tapped density ${ }^{6}$}

The measuring cylinder containing a known mass of blend was tapped for a fixed time. The minimum volume $\left(V_{t}\right)$ occupied in the cylinder and the weight (M) of the blend was measured. The tapped density was calculated using the following formula,

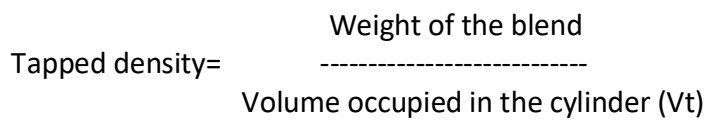




\section{Compressibility index ${ }^{7}$}

The simplest way for measurement of free flow of powder is compressibility, a indication of the ease with which a material can be induced to flow is given by compressibility index (I) which is calculated as follows,

$$
\mathrm{I}=\frac{\mathrm{Vo}-\mathrm{Vt}}{\mathrm{Vbx}}
$$

Here, $V_{o}$ is bulk volume and $V_{t}$ is tapped volume. The value below $15 \%$ indicates a powder with usually give rise to good flow characteristics, whereas above $25 \%$ indicate poor flow ability.

\section{Hausner's Ratio ${ }^{7}$}

Hausner's ratio is an indirect index of ease of powder flow. It is calculated by the following formula,

\begin{tabular}{|c|c|}
\hline & Tapped density \\
\hline ausner ratio = & Bulk density \\
\hline
\end{tabular}

Lower Hausner's ratio $(<1.25)$ indicates better flow properties than higher ones $(>1.25)$.

\section{Compression of tablets by using direct compression technique ${ }^{8,9}$}

Finally magnesium stearate was added to prepared blend. The mixed blend of drug and excipients was compressed using a single punch tablet punching machine at $30 \mathrm{PCl}$ to produce convex faced tablets, weighing 200 $\mathrm{mg}$ each with a diameter of $8 \mathrm{~mm}$. A minimum of 30 tablets were prepared for each batch.

\section{EVALUATION OF VALDECOXIB FAST DISSOLVING TABLETS}

Evaluation was done on tablets of all formulations batches considering following parameters and results were reported in Table no.3

\section{1) Weight variation test ${ }^{10}$}

Twenty tablets were selected randomly and average weight was determined. Then individual tablets were weighed and was compared with average weight. The comparison variation within the I.P limits, it passes the weight variation test.

\section{2) Tablet hardness ${ }^{6}$}

Tablet crushing strength $(\mathrm{Fc})$ or hardness, the force required to break a tablet in a diametric compression, was measured using Monsanto tablet hardness tester.

\section{3) Thickness ${ }^{11}$}

The thickness of individual tablets was measured using Vernier caliper, which permits accurate measurements and provides information of the variation between tablets.

\section{4) Wetting time ${ }^{12}$}

The wetting time of the tablets can be measured using a simple procedure. Five circular tissue papers of $10 \mathrm{~cm}$ diameter are placed in a Petri dish with a $10 \mathrm{~cm}$ diameter. Tem millimeters of water containing Eosin, a water soluble dye, is added to Petri dish. A tablet is carefully placed on the surface of the tissue paper. The time required for water to reach upper surface of the tablet is noted as a wetting time.

\section{5) Water absorption ratio ${ }^{10}$}

A piece of tissue paper folded twice was placed in a small Petri dish containing $6 \mathrm{ml}$ of water. A tablet was put on the paper and the time required for complete wetting was measured. The wetted tablet was then weighed. Water absorption ratio indicated with $\mathrm{R}$, which is calculated by using the below mentioned equation.

$$
R=10 \times \frac{\text { Wa }-- \text { Wb }}{\text { Wb }}
$$

\section{6) Drug content uniformity ${ }^{10}$}

Twenty tablets were weighed and taken in mortar and crushed to make powder. A quantity of powder weighing equivalent to 20 $\mathrm{mg}$ of Valdecoxib was taken in $100 \mathrm{ml}$ 
volumetric flask and $0.1 \mathrm{~N} \mathrm{NaOH}$ was added. It was then heated at $600 \mathrm{C}$ for 30 minutes. Then the solution was filtered using membrane filter $0.45 \mu \mathrm{m}$ and then the solutions absorbance was measured at $243 \mathrm{~nm}$. Then the amount of drug present was calculated using standard graph.

\section{7) Tablet friability ${ }^{8,9}$}

The friability of the tablets was measured in a Roche friabilator. Tablets of a known weight $\left(W_{0}\right)$ or a sample of 20 tablets were deducted in a drum for a fixed time (100 revolutions) and weighed (W) again. Percentage friability was calculated from the loss in weight as given in equation as below. The weight loss should not be more than $1 \%$. Determination was made in triplicate.

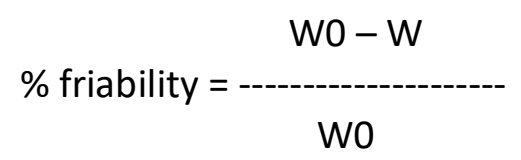

\section{8) In-Vitro Disintegration time ${ }^{13}$}

The test was carried out on 6 tablets using tablet disintegration tester ED - 20, Electrolab, distilled water at $37 \circ \mathrm{O} \mathrm{C} \pm 2^{\circ} \mathrm{C}$ was used as a disintegration media and the time in second taken for complete disintegration of the tablet with no palable mass remaining in the apparatus was measured in seconds.

\section{9) In vivo disintegration time}

The time required for the tablets to disperse in mouth cavity was determined by holding the tablets in mouth. The test was performed in 3 healthy human volunteers in the age group of 23 to 28 years.

\section{0) Dissolution studies ${ }^{14,15,16}$.}

In Vitro dissolution studies for all the prepared tablets and the marketed available tablets was carried out using USP paddle method at 50 $\mathrm{rpm}$ in $900 \mathrm{ml}$ of Sorenson's buffer solution (pH - 6.2) as dissolution media, maintained at $37 \pm 0.5$. $5 \mathrm{ml}$ of sample was withdrawn from the dissolution medium at the specified regular intervals, filtered through Whattmann filter paper and assayed spectrophotometrically at $243 \mathrm{~nm}$. An equal volume of pre warmed $(370 \mathrm{C})$ fresh medium was replaced into the dissolution medium after each sampling, to maintain the constant volume throughout the test. Then the cumulative percentage of drug release was calculated and represent graphically.

\section{RESULTS AND DISCUSSION}

Twelve formulations of Valdecoxib were prepared with different concentration of the four individual Superdisintegrants, Sodium Carboxy Methyl Cellulose, Crosspovidone, Polyvinyl Pyrrolidine, $\beta$-Cyclodextrin. For each formulation, blend of drug and excipients were prepared and evaluated for various parameters as explained earlier. The powder blend was compressed using direct compression technique. Bulk density was found in the range of $0.54-0.60 \mathrm{~g} / \mathrm{cm} 3$ and the tapped density between $0.65-0.69$ $\mathrm{g} / \mathrm{cm} 3$. By using these two density data, Hausner's ratio and compressibility index was calculated. The compressibility index was found between 13.24 and 17.8 and the compressibility correlation data indicated a fairly good flowability of the powder blend. The good flowability of the powder blend was also evidenced with angle of repose (range of $\left.24-32^{\circ}\right)$, which is below 40 indicating good flowability. Micromeretic results of the all batches were shown in Table no. 2.

Tablets were prepared using direct compression technique. Since the powder material was free flowing, tablets were obtained of uniform weight variations as per pharmacopoeial specifications. The drug content was found in the range of 96.21 $99.73 \%$ and the hardness of the tablets between 3.1 and 3.65, friability of the all batch tablets were found below $1 \%$ indicating a good mechanical resistance of tablets. The in vitro disintegration time of the tablets was found to be less than $60 \mathrm{sec}$. 
Super disintegrants accelerate disintegration of tablets by virtue of their ability to absorb a large amount of water when exposed to an aqueous environment. The absorption of water results in breaking of tablets and therefore faster disintegration. This disintegration is reported to have an effect on dissolution characteristics as well. Prepared fast dissolving tablet gets dispersed in the mouth quickly and releases the drug early as compared to its formulated conventional tablets. All the formulation in-vitro drug release results were mentioned in the Table no. 05 . The results revealed that the increase proportion of various polymers and superdisintegrants and solubilizing agent were associated with increase in the overall cumulative drug release rate. Release profile of CP 15(F-9) having 15\% Cross povidone prepared, using Mannitol (DC), Aerosil, Aspartame, flavor were found to have maximum release of $99.88 \%$ at the end of 10 minutes. The drug release from all batches was found to be concentration dependent on first order release kinetics.

The comparative in-vitro drug release of best prepared formulation (F-9) with marketly available Valdecoxib conventional table results were shown in the Table no. 6.

Table 1: Composition of fast dissolving tablets of valdecoxib.

\begin{tabular}{|l|l|l|l|l|l|l|l|l|l|l|}
\hline $\begin{array}{l}\text { Batch } \\
\text { Code }\end{array}$ & $\begin{array}{l}\text { Drug } \\
\text { in } \mathbf{~ m g}\end{array}$ & $\begin{array}{l}\text { PVP } \\
\text { in } \mathbf{m g}\end{array}$ & $\begin{array}{l}\text { SCMC } \\
\text { in } \mathbf{~ m g}\end{array}$ & $\begin{array}{l}\text { CP } \\
\text { in } \mathbf{m g}\end{array}$ & $\begin{array}{l}\text { BCD } \\
\text { in } \mathbf{~ m g}\end{array}$ & $\begin{array}{l}\text { Mannitol } \\
\text { in } \mathbf{m g}\end{array}$ & $\begin{array}{l}\text { Aerosil } \\
\text { in } \mathbf{~ m g}\end{array}$ & $\begin{array}{l}\text { Asparta } \\
\text { me in } \mathbf{~ m g}\end{array}$ & $\begin{array}{l}\text { Flavour } \\
\text { in } \mathbf{~ m g}\end{array}$ & $\begin{array}{l}\text { Mg. Stearate } \\
\text { in } \mathbf{~ m g}\end{array}$ \\
\hline F-1 & 20 & 7.5 & - & - & - & 108.5 & 3 & 4 & 5 & 2 \\
\hline F-2 & 20 & 15 & - & - & - & 101 & 3 & 4 & 5 & 2 \\
\hline F-3 & 20 & 22.5 & - & - & - & 93.5 & 3 & 4 & 5 & 2 \\
\hline F-4 & 20 & - & 7.5 & - & - & 108.5 & 3 & 4 & 5 & 2 \\
\hline F-5 & 20 & - & 15 & - & - & 101 & 3 & 4 & 5 & 2 \\
\hline F-6 & 202 & & 22.5 & - & - & 93.5 & - & 3 & 4 & 5 \\
\hline F-7 & 20 & - & - & 7.5 & - & 108.5 & 3 & 4 & 5 & 2 \\
\hline F-8 & 20 & - & - & 15 & - & 101 & 3 & 4 & 5 & 2 \\
\hline F-9 & 20 & - & - & 22.5 & - & 93.5 & 3 & 4 & 5 & 2 \\
\hline F10 & 20 & - & - & - & 7.5 & 108.5 & 3 & 4 & 5 & 2 \\
\hline F-11 & 20 & - & - & - & 15 & 101 & 3 & 4 & 5 & 2 \\
\hline F-12 & 20 & - & - & - & 22.5 & 93.5 & 3 & 4 & 5 & 2 \\
\hline
\end{tabular}

Table 2: Micromeretic properties of prepared blend

\begin{tabular}{|l|l|l|l|l|l|}
\hline $\begin{array}{l}\text { Formulation } \\
\text { Code }\end{array}$ & $\begin{array}{l}\text { Bulk density } \\
\text { (gm/ml) }\end{array}$ & $\begin{array}{l}\text { Tapped density } \\
(\mathbf{g m} / \mathbf{m l})\end{array}$ & $\begin{array}{l}\text { Angle of repose } \\
(\boldsymbol{\theta})\end{array}$ & $\begin{array}{l}\text { Percentage } \\
\text { compressibility }\end{array}$ & Hausner's Ratio \\
\hline $\mathrm{F}-1$ & 0.55 & 0.65 & 25.32 & 14.71 & 1.18 \\
\hline $\mathrm{F}-2$ & 0.54 & 0.67 & 24.65 & 16.35 & 1.24 \\
\hline $\mathrm{F}-3$ & 0.56 & 0.68 & 25.05 & 14.5 & 1.21 \\
\hline $\mathrm{F}-4$ & 0.58 & 0.66 & 27.6 & 15.4 & 1.13 \\
\hline $\mathrm{F}-5$ & 0.58 & 0.65 & 26.8 & 14.68 & 1.12 \\
\hline $\mathrm{F}-6$ & 0.60 & 0.67 & 28.9 & 13.24 & 1.11 \\
\hline $\mathrm{F}-7$ & 0.55 & 0.66 & 30.6 & 14.65 & 1.2 \\
\hline $\mathrm{F}-8$ & 0.57 & 0.68 & 29.6 & 14.6 & 1.17 \\
\hline $\mathrm{F}-9$ & 0.58 & 0.69 & 31.5 & 17.8 & 1.18 \\
\hline $\mathrm{F}-10$ & 0.57 & 0.65 & 32.4 & 15.6 & 1.14 \\
\hline $\mathrm{F}-11$ & 0.58 & 0.67 & 31.9 & 14.8 & 1.15 \\
\hline $\mathrm{F}-12$ & 0.59 & 0.68 & 32.6 & 14.45 & 1.15 \\
\hline
\end{tabular}


K Kareemuddin Ansari et al., Journal of Biomedical and Pharmaceutical Research

Table 3: evaluation of fast dissolving tablets of valdecoxib

\begin{tabular}{|c|c|c|c|c|}
\hline Formulation Code & $\begin{array}{l}\text { Weight variation } \\
\text { Test }\end{array}$ & $\begin{array}{l}\text { Hardness }(\mathrm{kg} / \mathrm{cm} 2) \\
\pm \mathrm{SD}\end{array}$ & $\begin{array}{l}\text { Thickness }(\mathrm{mm}) \pm \\
\text { SD }\end{array}$ & $\begin{array}{l}\text { Wetting time (Sec) } \\
\pm \text { SD }\end{array}$ \\
\hline $\mathrm{F}-1$ & Passes & $3.2 \pm 0.015$ & $2.73 \pm 0.07$ & $73.66 \pm 3.51$ \\
\hline$F-2$ & Passes & $3.25 \pm 0.11$ & $2.73 \pm 0.02$ & $74.33 \pm 4.72$ \\
\hline$F-3$ & Passes & $3.4 \pm 0.65$ & $2.70 \pm 0.15$ & $73.33 \pm 4.16$ \\
\hline$F-4$ & Passes & $3.5 \pm 0.45$ & $2.76 \pm 0.07$ & $71.66 \pm 3.05$ \\
\hline$F-5$ & Passes & $3.3 \pm 0.22$ & $2.73 \pm 0.04$ & $64.33 \pm 3.51$ \\
\hline$F-6$ & Passes & $3.65 \pm 0.56$ & $2.7 \pm 0.03$ & $70.33 \pm 8.02$ \\
\hline $\mathrm{F}-7$ & Passes & $3.4 \pm 0.21$ & $2.83 \pm 0.04$ & $44 . .66 \pm 3.05$ \\
\hline$F-8$ & Passes & $3.5 \pm 0.31$ & $2.81 \pm 0.4$ & $41.33 \pm 2.51$ \\
\hline$F-9$ & Passes & $3.6 \pm 0.11$ & $2.61 \pm 0.03$ & $37.33 \pm 2.51$ \\
\hline$F-10$ & Passes & $3.5 \pm 0.21$ & $2.73 \pm 0.04$ & $58.66 \pm 6.02$ \\
\hline$F-11$ & Passes & $3.4 \pm 0.24$ & $2.67 \pm 0.03$ & $53.33 \pm 7.02$ \\
\hline$F-12$ & Passes & $3.1 \pm 0.65$ & $2.74 \pm 0.4$ & $50.00 \pm 2.00$ \\
\hline
\end{tabular}

Table 4: Evaluation of fast dissolving tablets of valdecoxib

\begin{tabular}{|l|l|l|l|l|l|}
\hline $\begin{array}{l}\text { Formulation } \\
\text { Code }\end{array}$ & $\begin{array}{l}\text { Water absorption } \\
\text { ratio }\end{array}$ & $\begin{array}{l}\text { Drug content } \\
\text { (\%) }\end{array}$ & Friability (\%) & $\begin{array}{l}\text { In vitro } \\
\text { disintegration } \\
\text { time (Sec) }\end{array}$ & $\begin{array}{l}\text { In vivo } \\
\text { disintegration } \\
\text { time (Sec) }\end{array}$ \\
\hline$F-1$ & $8.508 \pm 0.05$ & 97.31 & 0.537 & $57.4 \pm 1.54$ & $46.32 \pm 0.21$ \\
\hline$F-2$ & $8.59 \pm 0.15$ & 96.25 & 0.403 & $51.6 \pm 2.43$ & $34.4 \pm 0.32$ \\
\hline$F-3$ & $8.315 \pm 0.23$ & 98.91 & 0.438 & $49.3 \pm 1.43$ & $32.5 \pm 0.65$ \\
\hline$F-4$ & $8.08 \pm 0.52$ & 97.89 & 0.502 & $35.6 \pm 2.45$ & $54.3 \pm 0.54$ \\
\hline$F-5$ & $8.09 \pm 0.45$ & 98.72 & 0.468 & $33.6 \pm 3.42$ & $46.7 \pm 0.75$ \\
\hline$F-6$ & $8.99 \pm 0.56$ & 99.17 & 0.367 & $34.6 \pm 1.65$ & $35.5 \pm 0.24$ \\
\hline$F-7$ & $9.86 \pm 1.12$ & 97.30 & 0.402 & $35.4 \pm 2.1$ & $43.6 \pm 0.56$ \\
\hline$F-8$ & $10.8 \pm 0.54$ & 97.62 & 0.402 & $32.1 \pm 0.2$ & $35.7 \pm 0.7$ \\
\hline$F-9$ & $10.1 \pm 0.67$ & 99.73 & 0.334 & $28.3 \pm 0.15$ & $29.5 \pm 0.6$ \\
\hline$F-10$ & $9.06 \pm 0.54$ & 97.30 & 0.434 & $32.4 \pm 1.87$ & $37.8 \pm 0.43$ \\
\hline$F-11$ & $9.32 \pm 0.52$ & 97.62 & 0.469 & $35.6 \pm 1.4$ & $34.8 \pm 0.57$ \\
\hline$F-12$ & $9.43 \pm 0.43$ & 97.73 & 0.503 & $32.5 \pm 0.54$ & $33.6 \pm 0.23$ \\
\hline
\end{tabular}

Table 5: In-vitro drug release for prepared formulations of FDT

\begin{tabular}{|c|c|c|c|c|c|c|c|c|c|c|c|c|}
\hline \multirow{2}{*}{$\begin{array}{l}\text { Time in } \\
\text { Cumulative } \\
\text { Percentage } \\
\text { of drug } \\
\text { release } \\
\text { minutes }\end{array}$} & \multicolumn{12}{|c|}{ Cumulative Percentage of drug release } \\
\hline & F - 1 & $F-2$ & $F-3$ & $F-4$ & F - 5 & $F-6$ & F - 7 & F - 8 & F - 9 & $F-10$ & F -11 & F - 12 \\
\hline 1 & 62.41 & 65.53 & 71.14 & 54.31 & 60.54 & 66.15 & 77.37 & 79.24 & 82.98 & 70.52 & 72.39 & 76.75 \\
\hline 2 & 66.25 & 70.62 & 74.99 & 58.13 & 62.51 & 68.75 & 80.61 & 84.97 & 86.23 & 74.36 & 75.61 & 80.61 \\
\hline 4 & 69.47 & 74.46 & 76.97 & 63.21 & 64.47 & 70.72 & 83.22 & 89.47 & 88.85 & 81.96 & 85.08 & 83.22 \\
\hline 6 & 71.4 & 77.70 & 82.08 & 65.80 & 69.56 & 75.82 & 88.34 & 95.21 & 93.97 & 84.58 & 87.70 & 86.47 \\
\hline 8 & 77.16 & 81.55 & 85.94 & 70.89 & 75.90 & 79.67 & 93.46 & 97.23 & 97.86 & 87.82 & 89.08 & 89.72 \\
\hline 10 & 81.02 & 84.80 & 88.57 & 73.49 & 79.13 & 83.54 & 96.72 & 98 & 99.88 & 89.20 & 91.71 & 93.59 \\
\hline
\end{tabular}


Table 6: comparative drug release studies of best formulation and marketed sample of fast dissolving tablets of valdecoxib.

\begin{tabular}{|l|l|l|}
\hline \multirow{2}{*}{$\begin{array}{l}\text { Time in } \\
\text { minutes }\end{array}$} & \multicolumn{2}{|l|}{ Cumulative percentage drug release } \\
\cline { 2 - 3 } & Best Formulation F-9 & Marketed Sample \\
\hline 1 & 82.98 & 31.87 \\
\hline 2 & 86.23 & 41.27 \\
\hline 4 & 88.85 & 45.69 \\
\hline 6 & 93.97 & 53.87 \\
\hline 8 & 97.86 & 60.81 \\
\hline 10 & 99.88 & 65.26 \\
\hline
\end{tabular}

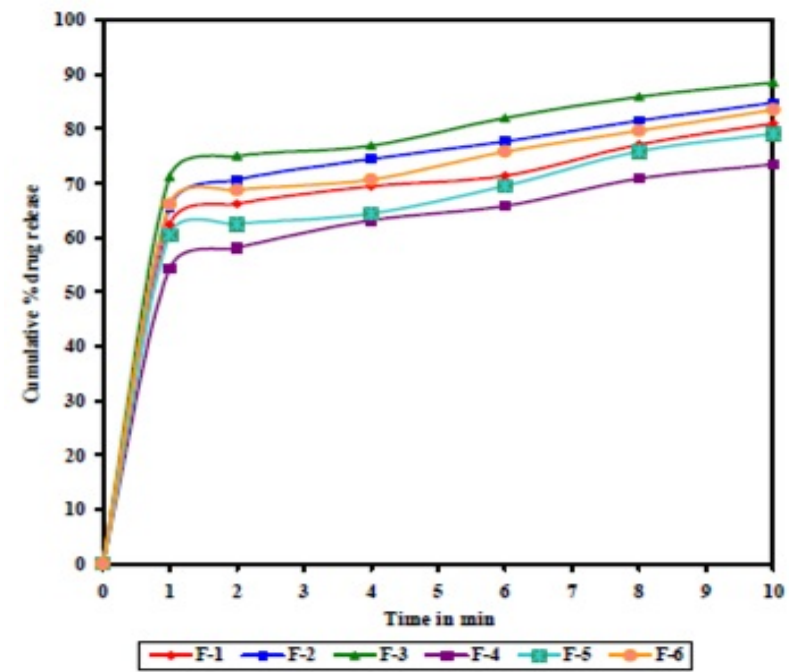

Figure 1: cumulative $\%$ drug release vs. time in min from prepared batches F-1, F-2, F-3, F-4, F-5 \& F6 of fast dissolving tablets of valdecoxib.

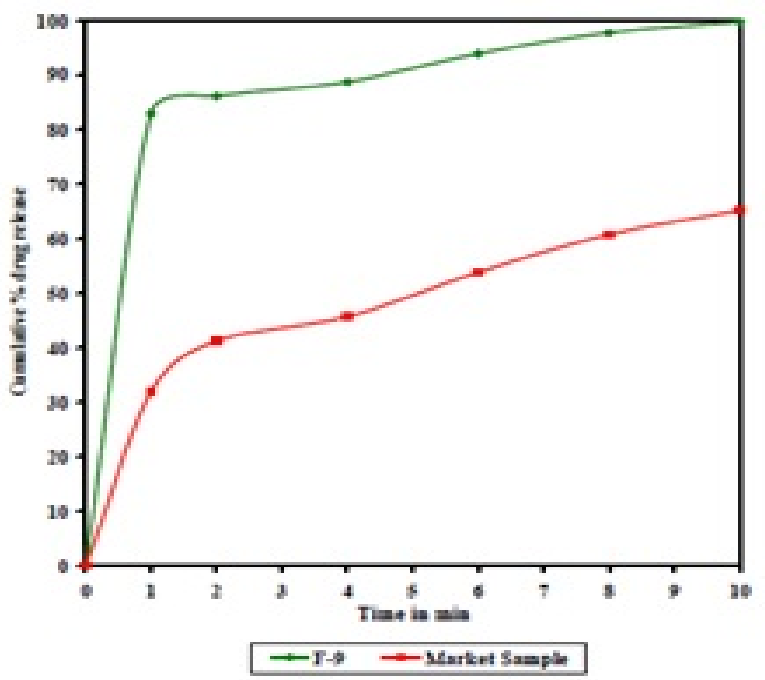

Figure 2: plot showing relation between cumulative \% drug release vs time in min from marketed sample \& best formulation F-9 


\section{CONCLUSSION}

In the present work efforts have been made to prepare and evaluate fast dissolving tablets of Valdecoxib using various superdisintegrants, polymers and solubilizing agent. The results revealed that the increase proportion of various polymers and superdisintegrants and solubilizing agent were associated with increase in the overall cumulative drug release rate. Release profile of CP 15(F-9) having 15\% Crospovidone prepared using Mannitol (DC), Aerosil, Aspartame, flavor were found to have maximum release of $99.88 \%$ at the end of 10 minutes. The drug release from all batches was found to be concentration dependent on first order release kinetics. The fast dissolving tablets (FDT) found to have excellent physical characters. The superdisintegrants were also found to be compatible with the other excipients of the formulation as well as with drug, which is evident from the drug content values. Comparative drug release study revealed that the formulated fast dissolving tablets (FDT) have more rapid drug release effect than the marketed available formulation. Hence the formulation of CP-15 (F-9) fulfills the objective of the present study.

\section{REFERENCES}

1. Seager $H$, Drug - delivery products and the Zydus fast-dissolving dosage form, J Pharm Pharmacol, 1998; 50:375 - 82.

2. Kaushik D., Dureja $S$ and Saini T.R., Mouth dissolving tablets - A Review, Indian Drugs 2003; 41(4):187 - 193.

3. Indurwade N.H, Rajyaguru T.H, and Nakhat P.D, Novel approach in fast dissolving tablets, Indian drugs, 39(8):405 - 409.

4. Hiremath J.G, Shastry C.S and Srinath M.S, pharmaceutical approaches of taste masking in oral dosage form, Indian drugs, 2004; 41(5):253-257.
5. Fukami J et al, evaluation of rapidly disintegrating tablets containing glycine and carboxymethylcellulose. Int J Pharm. 2006; 310:101 - 109.

6. Marshall K., In; Lachman L., Liberman H.A., Kanig J.L., Eds., theory and practice of industrial pharmacy, 3rd Edn, Varghese Publishing house, Mumbai, 1987; 66 - 99.

7. Lindberg N., Palsson M., pihl A., Freeman R., Freeman T., Zetzener $\mathrm{H}$ and Enstad G., Flowability measurements of pharmaceutical powder mixtures with poor flow using five different techniques. Drug dev. Ind Pharm. 2004; 30(7):785 791.

8. Kumaran V, Sathyanarayana D, Manna P.K, Chandrasekar G, Manavalan R and Naik R.P, formulation development of acetaminophen tablets by direct compression and its pharmacoeconomics, Indian drugs, 2004; 41(8):473 - 477.

9. Patel D.M, patel, N.M, Shah R.R, Jogani P.D and Balapatel A.I, Studies on formulation of Orodispersible tablets of Refocoxib, Indian journal of pharmaceutical sciences, 2004; $621-625$.

10. Popa $G$ and Gafitanu E., Rev Med Chir Soc Med Nat lasi. Apr - Jun 2003; 107(2):33742.

11. Lachman $L$, Lieberman $A$ and Kinig $J L$, the Theory and practice of Industrial Pharmacy, $4^{\text {th }}$ Ed, Varghese Publishing House, Bombay, 1991; 67-68.

12. Battu SK, Repay MA, Maunder S and Rio MY, Formulation and evaluation of rapidly disintegrating tablet Fenoverine tablets: Effect of Superdisintegrants, Drug Dev Ind Pharm, 2007; 33:1225-1232.

13. Sreenivas S.A, Gadad A.P "formulation and evaluation of Ondancetron $\mathrm{HCl}$ directly compressed mouth disintegrating tablets'. Indian Drugs, 2006; 43(1):35-38.

14. Shirwaikar A.A and Ramesh A., fast disintegrating tablets of Atenolol by dry granulation method, Indian journal of 
K Kareemuddin Ansari et al., Journal of Biomedical and Pharmaceutical Research

pharmaceutical sciences, July - Aug 2004; 422-426.

15. Nayak S.M and Gopalkumar P., Design and optimization of fast dissolving tablets for Promethazine theoclate, Indian drugs, 2004; 41(9):554-556. .
16. Kuchekar B.S, Badhan A.C, and Mahajan H.S., Mouth dissolving tablets of Salbutamol sulphate a novel drug delivery system, Indian Drugs, 2004; 41(10):592 598. 